\title{
Final Report on PCRV Thermal Cylinder Axial Tendon Failures
}

\author{
D. A. Canonico \\ J. C. Griess \\ G. C. Robinson
}
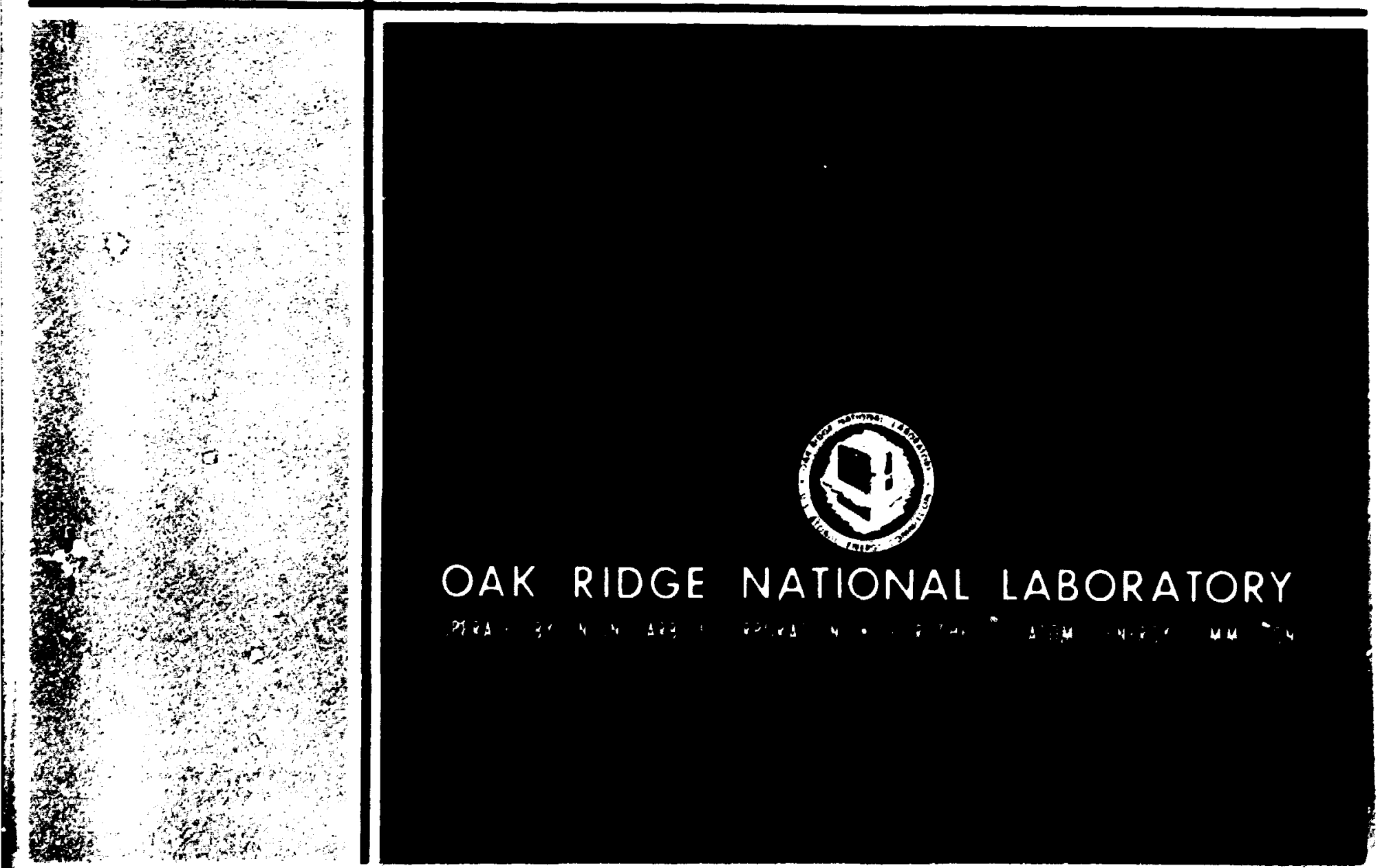
BLANK PAGE 
Printed in the United States of America. Avalable from National Technical Information Service

U.S. Depariment of Commerce

5z85 Porr Royal Road. Springfietd. Virginia 22161

Price: Printed Copy 55.00: Microfuche \$2.25

Thus report wes prepored as an account of work ponsoned or the United States Government. Nerther the United States nor the Energy Researeh and Dewlosmme Adin nistration. nor any of thew emplovess. nor amy of thew contracton. subcontractors. Or their emplowes, makes any werranty. express or mupined. or asumes any lapd liablity or repensibility for the acewary. completenes or

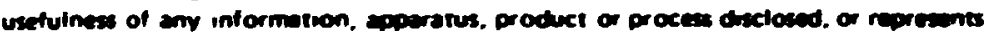
thet its use would not miringe proventy owned ryts. 
ORSI.-5110

(IC-77 Cras-Cooled

Reacter Technology)

Contract So. H-7405-eng-26

MFTALS ASD CERIYICS DIVISIOS:

FISA:. REPIKT ON PCRI THERQHI. CYIISDER

LIJA. TESDON FIII.LRES

D. A. Cannnico, J. C. Griess, and $r$, C. Robinson

JANUARY 1976

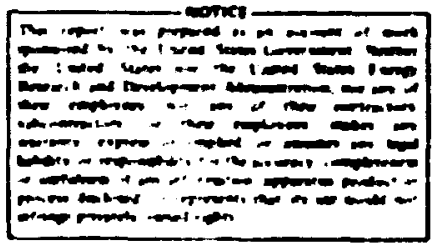

OAK RIMFF SATIONAL. IABORATORI

Oak Ridge, Tennessee $\mathbf{3 7 8 3 0}$

operated by

IXIIAS GARBIDF CORPORATION

for the

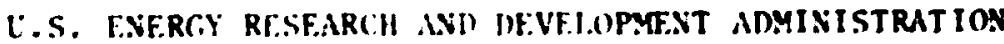




\section{CONTENTS}

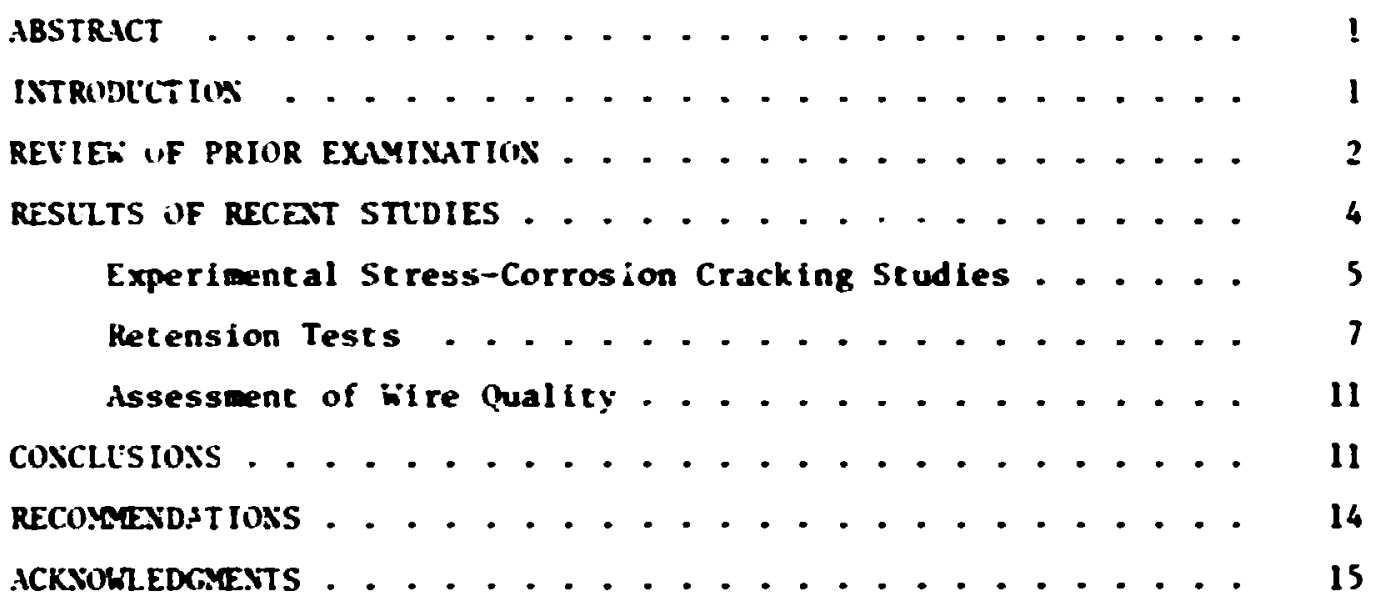




\title{
FISAL REPORT CX PCBV THERHLL CYLIXDER NIAL IEMON FAILURES
}

D. A. Canonico, J. C. Griess, and G. C. Robinson?

\begin{abstract}
ARSTRACT
The pozt-test exanination of the falled tendons fro the PCRV theral cylinder eaperinent has been concluded. Fallures in the wires are attributed to seress-corrosion cracking. The cause of the tendon fallures has not been unequivocably established, but they wy have beea due to nicratss in the duct. The wires erployed in the nanufacture of the cendons vill crack in less than $72 \mathrm{hr}$ in a $0.2 \because$ solution of armion nitrate at $70^{\circ} \mathrm{C}$. The quality of the wires is por:, and surface cracks vere detected. These could have icted as coacentrating sites for both stress and the deleterious contsinants. We feel that the factors that led to the fatlures in the thermal cylinder experiment were unique. An improper formulation of the epoxy resin did not provide the cendon anchor plate seal that was desired; Indeed, the inproper formation 1s responsible for the high level of nitrogen in the ducts of the falled cendons.
\end{abstract}

\section{InTHOUCTION}

In May 1973 the Prestressed Concrete Reactor Vessel (PCAV) thernol cylinder test was ternianted. Durfag detcasionias it was found that nearly all of the inner rou ASTM A 416 prestressing cendons had falled during the 11 fetinc of the experiment. An in-depth study sought the cause of the cendon fallures. Previous work was reported in curo incerin reports. The first ${ }^{2}$ discused the PCat theral cyliader expennent. The second ${ }^{3}$ presented the results of preliatnary observations and studies and serves as the background for this final report. It spectfically discussed the tendon fallures up to the time of lts issuace. The sumery from that report is provided.

IReactor Diviston.

${ }^{2}$ G. D. Whitman, Irterir Peport on PCPV Thermai Cytinder Ariat tericr. Faiturea, ond-Th-4763 (December 1976).

'D. A. Canonico, Secoud interir. Report or. PCPV Therral Oglirder nixial fendon Failures, OML-TH-4764 (Noveder 1974). 
"The postcest exanination of the tendons from the PCRY thermal cylinder cests is continuing. It has been shown to date chat the failures have occurred both before and after the hot-spet cest. The failures occur in the inner row and do appear to be due to a stress corrosion phenomenor. The evidence co date ceods to niniaize the probability that iydrogen esbritclement is responsible for the cendon failures. A successful stress-cortosion cracking (SCC) iest has been conducted; however. the conditions were ext rewely severe. Failure occurred in $\mathbf{4 2 0} \mathrm{hr}$. The final failure is by ductile mode; chere is no evidenre of a britcle failure echanism. A cup-cone fracture, Initiated by a loss of cross section. is the prevailing orphologr.

The cendons that haye falled contain wax that is enriched in chlorine and nitrogen. Further, an aqueous liquid has been obtained ard analyzed. It too has a high nitrogen content. It is certain that wisture entered the ducts surtounding the cendon. there is evidence that the epoxy resin was incorrectly formlated and that iree amonia was preseni in the region of the bottoe anchor plates. In SCC mechanisa incorporating the free asmonia and carbon dioxide from the armosphere has been postulaced atid cesis to prove this theory are under way."

Since the issuance of the interia report in Noveber 1974, additional studies have been conducted to explain the cause of the tendon failures. This report addresses itself to the results and conclusions that we re derived $f$ on these studies, and constitites the completion of the netallurgical examination of the failed tendons.

\section{REVIEU OF FRIOR EXAYISATIJN}

Figure 1 is a sketch $c$ the axial tendon assexblies. The tendons vere enclosed within the duct as shown. The wites (ASTM A 426) were coaced with W-OX-ID " $A$ " by the manufacturet of tho cendons." and the ducts were filled with Mobilwax 2300-T5L6 during the assembly of the thermal cyifinder experiment. Tendon failures occurred randonly during the Iffetine of the experinent, as shom by the load-tine curves obtained with instrumented tendons (see Figs. 9 thru 16 of Ref. 2). nil example of a typical fracture is shoun in Fig. 2. All the wire failures contained - flat seai-elliptical inietation stce and a ductile cup-cone fracture when the net area of the uire was not able to withstand the stressing load. (The initiation sfte in the wire shom in Fig. 2 contained sulfur, but this was not necessarily true of all of the failures.) The wax in the ducts of the disassewbled thermal cylinder test was. cheaically analyzed, and the results are given in Table 1 . For comparison, the as-Tezelved s0-0X-ID "A" Special and Mobtlwax 2300-T5L6 are included. it is evident that the wax in the tendon ducts contained large quantities of nitrogen. Although the chemical form of nitrogen was not determined,

\footnotetext{
Corroston inhibitor manufact:ired by Dearborn Chemical Division of
}

W. R. Grace and Company. 


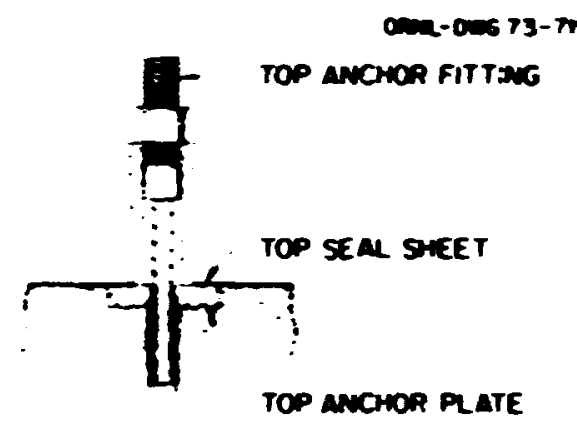

- UPFER DUCT

LOUER OUCT -

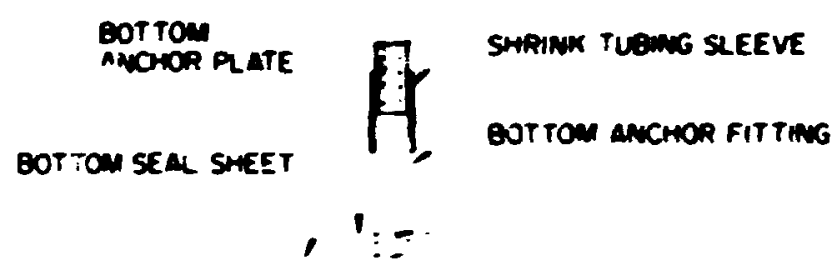

Fig. 1. Axial Tendon Subassembly.

the wax had a strong odor of andonis when it was initiaily rewoved froe the ducts. This was true for the wax from ducts that concained falled tendons (tendons 19 and 28 ) as well as for that caken from a duct in which the tendon did not fall (No. 44). The presence of nitrogen in the wax could not be explained on the basis of its presence in the wo-0X-ID (high Itrogen but very little Mn-0I-ID vas used to cant the wires) or in the Hobilwax (Where large quantities are waed but the nitrogen level was low). A review of the experimental procedure revealed that the presence of nitrogen and perhaps the high wotsture content could probably be traced to an improper formulation of the epoxy sealer. 


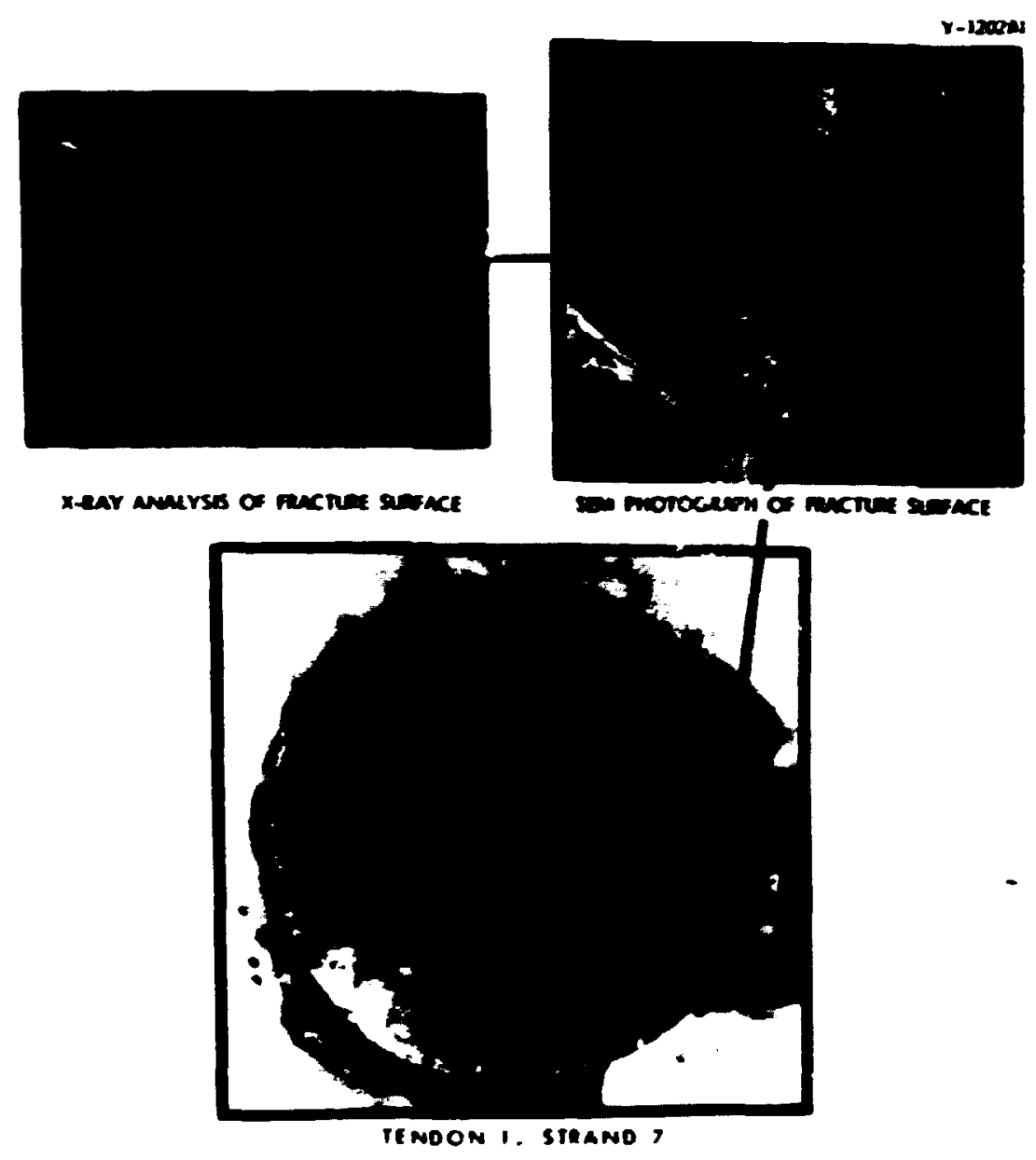

F18. 2. Fractographic Examination of railure Surfare in a dire fro= iendor 1. The flat area in the photomacrograph was viewed and analyzed in the scanning electron microscope. There is a definite indication cf sulfur in the flat area of the fracture surfact.

Further, visual inspection of the wi: : : fluoride shrink tuing on several of the removed tendon assemblies indicated that the seal design was ineffective in preventing water ingress $\mathrm{frnm}$ the concrete.

\section{RESLLTS OF RECENT STCDIFS}

During the past year se have investigated the probahle mechanisa(s) that could explain the tendon wire fallures. In addition, the effect of the cemperature difference between the outer row and inner row tendons on the preferential location of the failures was studied, and some randomly selected wires (from the seven-wite tendons) were exanined merallographicaliy. 
Table 1. Cnemical Analysis of the PCRV Thernal Cylinder Test Uax

\begin{tabular}{|c|c|c|c|c|}
\hline \multirow{2}{*}{$\begin{array}{l}\text { Ident if ication } \\
\text { of Source } \\
\text { of liax }\end{array}$} & \multicolumn{4}{|c|}{ Level of Contaninant, ppe } \\
\hline & Cl & $\mathbf{s}$ & $x$ & $\mathrm{H}_{2} \mathrm{O}$ \\
\hline As-received So-ox-ID & $\begin{array}{l}3.1 \\
2.1 \\
2.4\end{array}$ & 1900 & 785 & 76 \\
\hline $\begin{array}{l}\text { As-received } \\
\text { Yobil lwax 2300-TSLE }\end{array}$ & $\begin{array}{l}3.6 \\
7.6 \\
2.7\end{array}$ & 3200 & 200 & 32 \\
\hline $\begin{array}{l}\text { Lax Resoved Fron } \\
\text { Tendon } 19^{\mathrm{a}} \\
\text { Tendon } 28^{\mathrm{a}} \\
\text { Tendon } 44^{\mathrm{b}}\end{array}$ & & & $\begin{array}{r}840 \\
6400 \\
1000\end{array}$ & $\begin{array}{r}1,900 \\
25,585 \\
24,800\end{array}$ \\
\hline
\end{tabular}

\section{Experimental Stress-Corrosion Cracking Studies}

As previously ${ }^{2}$ indicated, a strong amonta odor was associaced with the wolst wax from the disassembled ducts of the thermal cylfader test. Subsequent analysis of some of the liquid shoued it to be in aqueous solution containing nitrogen, chlorine, sulfur, and perhaps other substances. The ni:rogen appeared to be nostly in the for of amonia (or perhaps a volatile anine), but in a feu cases lou levels of nitrate ( $.50 \mathrm{ppm}$ ) were alsn present. Decause of the swall volumes of solution, complete analysis was not possitle. From the above observations and the known applied stress levels in the cendons, stress-corrosion cracking appeared to be the nost likely cause of failure.

The amionia apparently originated from the incortect formulation of the epoxy sealer used to coat the botton sea'. plates and the top concrete surface of the thermal cylinder. Excrss hardener was used in preparation of the sealer. Hardeners used wit: epoxy resins contain organic anines, which can hydrolyze in the presence of water to produce anconia.

Various amonion salts, such as nitrace and carbonate, are known ro be capable of producing stress-corrosion cracking in steels. To decerane whether the steel in question was susceptible to cracking in such environments, several U-bend specimens of the steel were exposed to various solutions that contained certain amoniun salts and the eprxy alxiures. 
the test environment was the incortectiy formulated epoxy resin used in the thermal cylinder test. A mixture with a large excess of nardener (large enough that the axture did not harden) was placed on a shelf in a closed container, and under it was placed the sane volune of water. After equilibration for one week the amonia concent ration of the water was $0.2 \therefore$. At that $t$ ine sanples of both the water and the resin were taken for use as test solutions. Then carbon dioxice was added to the system, and after a week both phases were resanled. Other test environments inciuded 0.2 and $2.0 \because$ and saturated amoniu nicrate. $0.1,0.2,0.5$, and $1.0 \because$ and saturated ameniun carbonzte, and the sane carbonate solutions with 50 ppa nitrate (as lawis) added.

The test specinens were ads from the cercer wires of uncracked circuaferencial tendons taken fron the theral cylinder experiment. The se were centerless ground to a dianeter of 0.060 in. $(1.5 \mathrm{~m})$. Then H-ia. (i6-w) lengths of the steel were bent into saall-zicit: $\mathrm{I}^{\prime}$ s, and the legs were held essentially parallel by insertion in sinort pleces of sintered aluninum oxide insulation containing two holes. The wires were both plastically and elastically deforned. Figure 3 shows a typical test specinen. The swall t-berds were placed in 25-al Pyrex bottles containing $15 \mathrm{al}$ of test solution. Plastic-lined screw-cop lids sealed the containers against evaporation. The botcles were placed in a swall oven ield at the desired temperature.

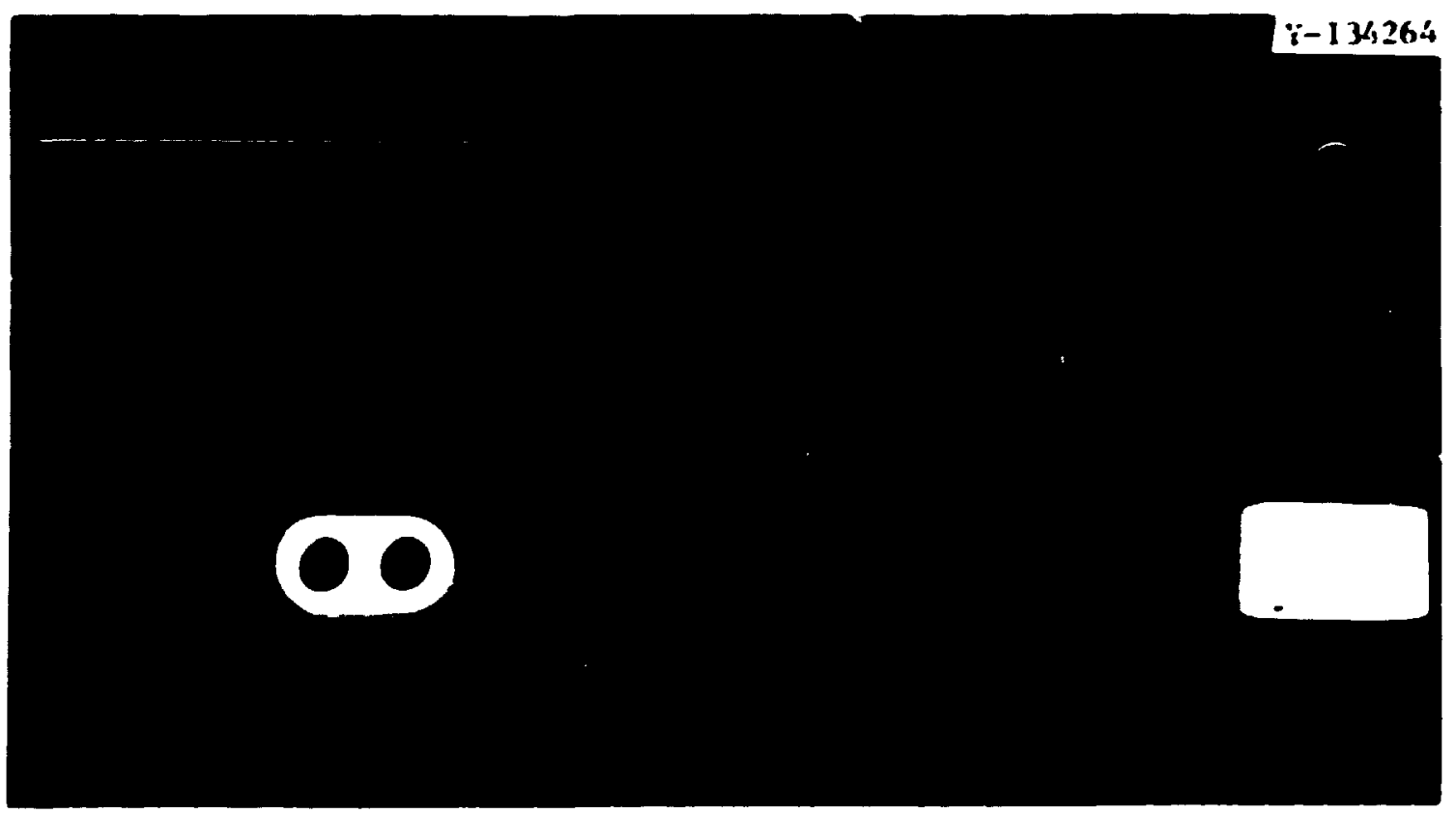

Fig. 3. The U-bend Specimen Used in the Stress-Corrosion Studies. The 0.060-in.-dian (1.5-m) sceel cest section was ground from a sound arca of a wire remoned from a cendon in which individual wires had failed. The wire is bent into the $U$ configuration, and $t$ s ends are placed in the refractory retitiner. 
Lo cracks were found in the sperimens exposed in either epoxaixiure (witin or bitiout '1") or in the water equilibrated with tiet during exposures that lastec 96 days at $70^{\circ} \mathrm{C}$. Similar iests in the same environments to which 50 pron nitrate had been added produced the sabe results during a 100 -day test at $66^{\circ} \mathrm{C}$. Also cracking was comple:el: absent in all concentrations of amoniun carbonate solut ions under the above conditions, either with or withou: 50 ppm nitrate added.

Cracking was noted only in the 0.2 and $2.0 \because$ amoni un gitratc solutions. In the $0.2 \because$ solution at $70^{\circ} \mathrm{C}$. duplicate specimens cracked in three da:s. Inder the same conditions the one specimen exposed to the $2.0 \%$ selution cracked in the $t$ ime interval between 7 and 10 cays. $\therefore$ failed spacizen is shown in Fig. 4. Failures in the other two l-bend specimens luoiked aloost identical to the one shoin. The one speciber exposed to the saturated soiution of amonium nitrate at $70^{\circ} \mathrm{C}$ dic not crack during the 94 -day test.

The above results sinow that the steel from which the tendons vere made is suscept ible to st ress-corrosion cracking in 0.2 and $2.0:$ ammonium nitrate, but not in very dilute soluticns ( $50 \mathrm{ppm}$ ) or in ver: concentrated solutions (saturated at test temperatues). However, in certain regions along the tendons higher concertration of the dilute nitrate solution could have occurred, in which case cracixing rertainly: coulc hate resulied. Although our results do not allow one to conclude unequivocally that amonium nitrate was responsible for the observed cracking. they do nut exclude the possibiliey that cracixing resulted from nitrate present in she aqueous environment.

\section{Retension Tests}

is previcusly noced, the observed failures were associated stich the inner row ct tendons. This itolies either a preferential location for the corrodent (s) or a sensitivity to the slight difference in temperature experienced by the outer and inner row of tendons 152 vs $38^{\circ} \mathrm{C}$ ( 125 vs $\left.100^{\circ} \mathrm{F}\right)$ ). A cest was prepared to examine sensitivity to temperature. he assumed that the corrodent(s) was still present in the ducts and that a reversal in the radial temperacure gradient rould, in time, result in a failure of an outer-row cendon. On these premises, two pie-shaped segments were removed from the PCRV thermal cylinder test. one inc! uding cenduns 15 and 39 , the other tendons 20 and 45 (see Fig. 5).

Each segment was out itted on the outside cylindrical surface tith silicone rubber electric strip heaters and on the radial cuts imediately adjacent to the inaide circumferential surface with Panelcoil heat exchangers as shown in rig. 6. Fach tendon was equipped with a calibrated load cell, the output of which was continnously recorded by a multipoint recorder. Thermocouples were ewbedded in the inner and outer cylindrical faces of the segments; temperatures were continuously recorded by a mulcipoint recorder. Heater Input was controlled by manually adjustah le Variac voltage control and by a teaperature controller.

In August 20, 1974. tendons 20 and 45 in one segment and tendon 39 in the second segment were retensioned. Tendons 45 and 39 were retensinned to the design load of 36,200 is $(162.2 \mathrm{kN})$. At that load tendon 39 shmued 


$$
\supseteqq
$$




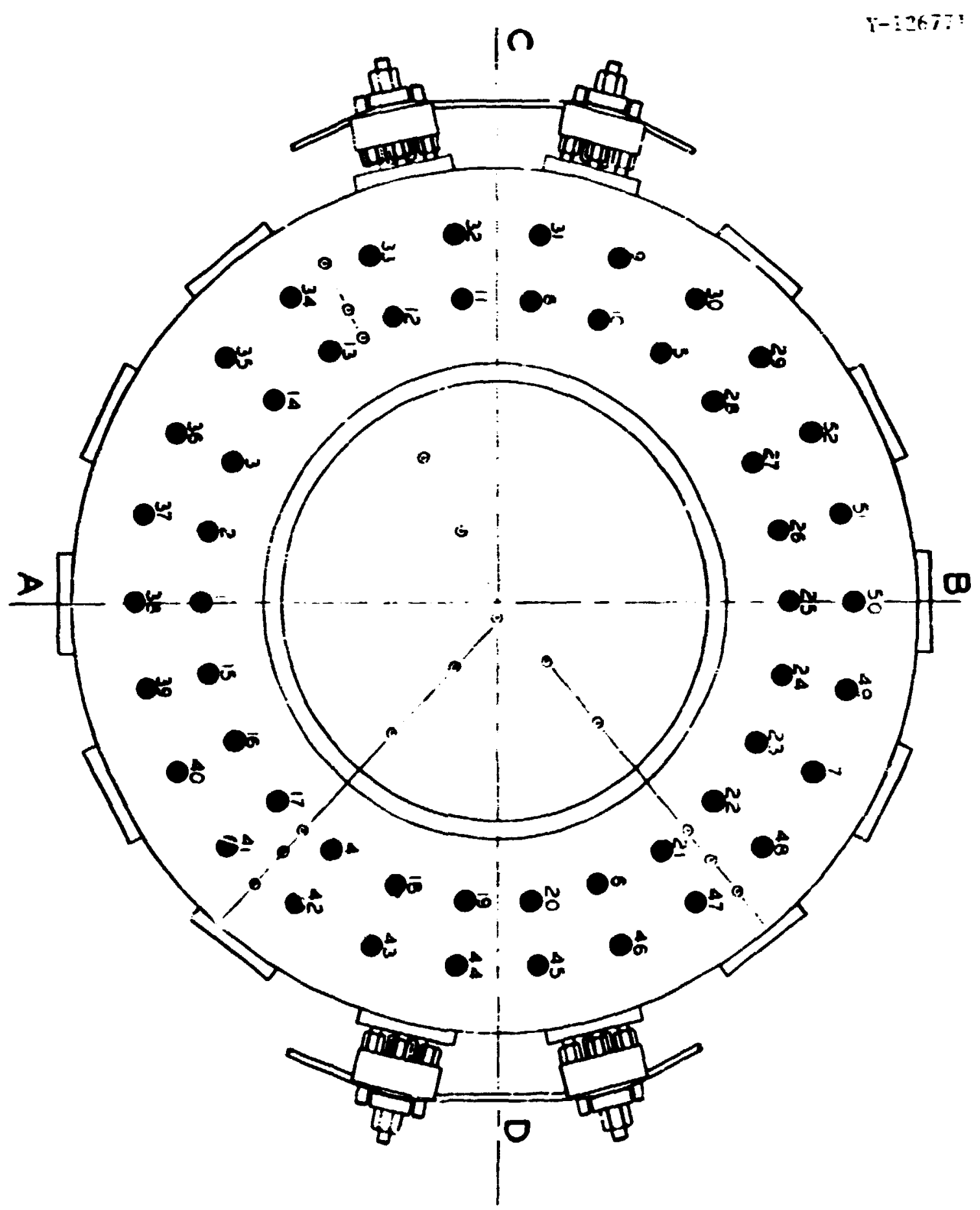

Fig. 5. Location of Tendon Assentlies in the Prestressed Concrete Reactor Vessel Thermal Cylinder Test. 


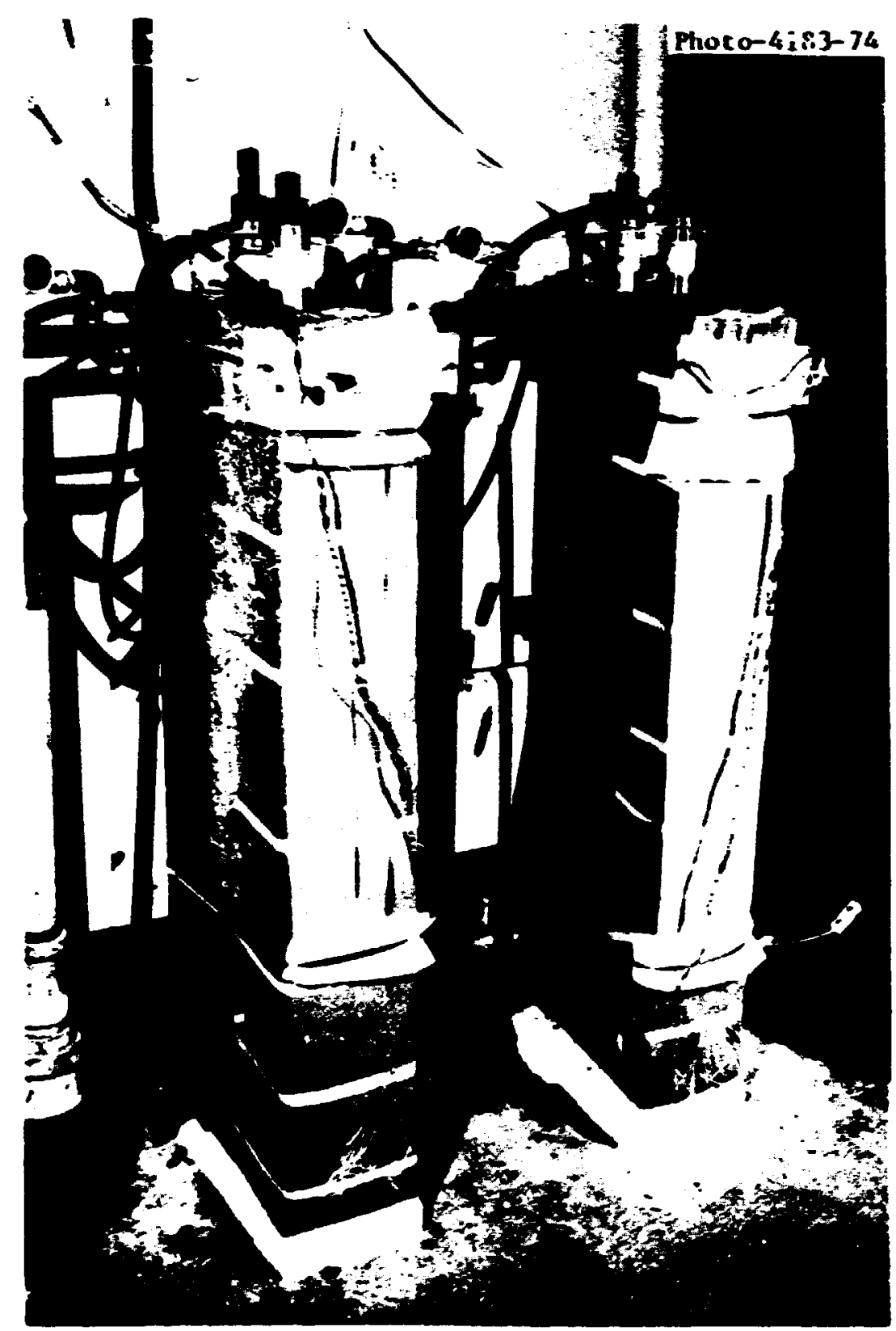

Fig. 6. Panelcoils and Electric Strip Heaters on segments of Thermal Cylinder Test Before Being Insulated.

distress, as indicated by audible popping sounds. Following transfer of the load to the concrete anchors, the load in tendon 39 dropped to $18,900 \mathrm{lb}(84.1 \mathrm{~kW})$, thereby indicating that several wires had broken. Tendon 20 was subjected to a reduced loading of $19,50016(86.7 \mathrm{kN})$ because of observed departures from measured 1 ínear load-extension response. Tendon 15 was not stressed since it had failed during the earlier detensioning of the thermal cylinder model. 
Upon completion of the restressing operation the heat exchangers for the two concrete segments vere descaled and passivated. Corrosion inhibition was initiated and the prescribed thernal conditions of $66^{\circ} \mathrm{C}$ $\left(150^{\circ} \mathrm{F}\right)$ on the outside and $26^{\circ} \mathrm{C}\left(75^{\circ} \mathrm{F}\right)$ on the inside vere instituted on August 30, 1974. The lands on the tendons and temperatures of the segments were then wonitored continwously until termination of this task.

Durfag the intervening period no significant changes in load occurred. Appareatly, the factors leadine to the previously observed failures were no Ionger active or never existed in the ducts cested. The load loss exhibited by cendon 39 during retensioning was probably - consequence of the eavironantal conditions existins during operation of the thernal cylinder test. The reversed thermal gradient imposed or: the segants had no observable effect.

\section{Acsessinent of Wire Quality}

During the course of this investigation, numerous incideaces of poor wire quality were noted. Som of these observations vere previously ${ }^{5}$ reported. Since the release of the interin report additional studies of randonly selected wires have revealed that the wires in the cendons used in the therel cylinder test vere of questionable quality. Locating defective areas in the wires is fortuitous. Radiographic examinations of randonly selected wires removed from archive (unused) tendons fid not reveal any evidence of defects in the wires. However, metallographic exanination of these "acceptable" wires revealed fine hairline cracks. Figures 7 and 8 contain typical photonicrographs of the types of defects obse-ved. These cracks are not detectable by the usus: exanination standards. The wos: daming evidence was obtained during the centerless grinding of the wires before the preparation of the U-ijend stress corrosion test specimens. During grinding one wire suple separated into two pieces: a metallographic examination of the wire revealed the quality show in Fig. 9. These fissurelike cracks could serve as both locations for concentrating any contaninants present and seress concent rat ing sites. Thus, these cracks could have cont:sbuted to the failures observed in the thermal cylinder test.

\section{concl.essons}

1. The tendon corrosion problem experienced during the Thermal Cylinder Experiment is fairly unique because of the particular combinacion of materials employed. A similar set ni corditims should not orrur in a prototype Prestreased Conerete Reactor Vessel. In general,

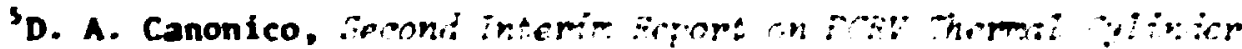
Arial Tendon Failups, ORNL-TH-4754 (Novenber 1974). 

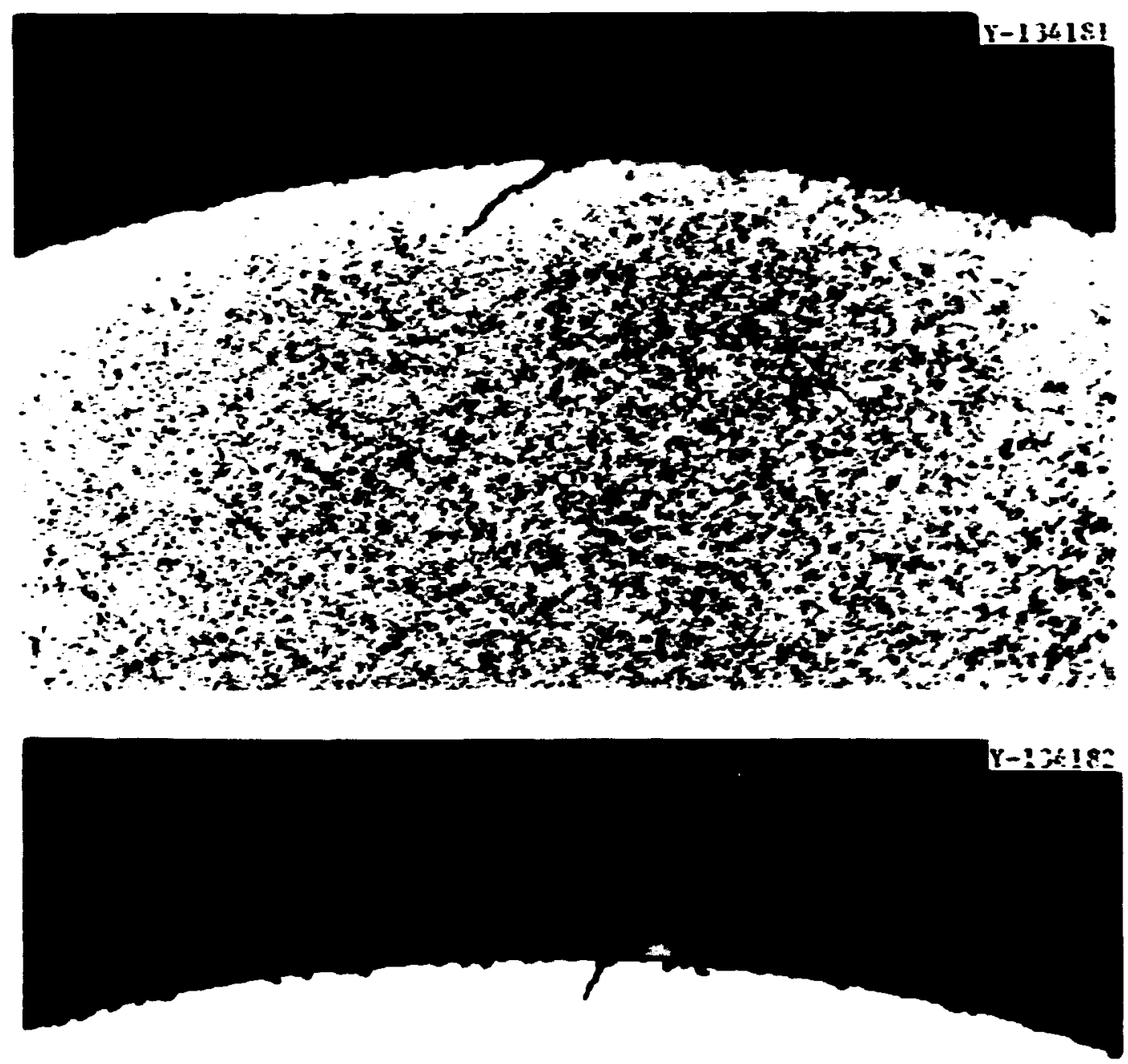

Fig. 7. Surface Defects in a Wire Used in the Manufacture of Tendons. 100x. These surface laps could serve as concentrating sites for contaminants that cause stress-corrosion cracking. 


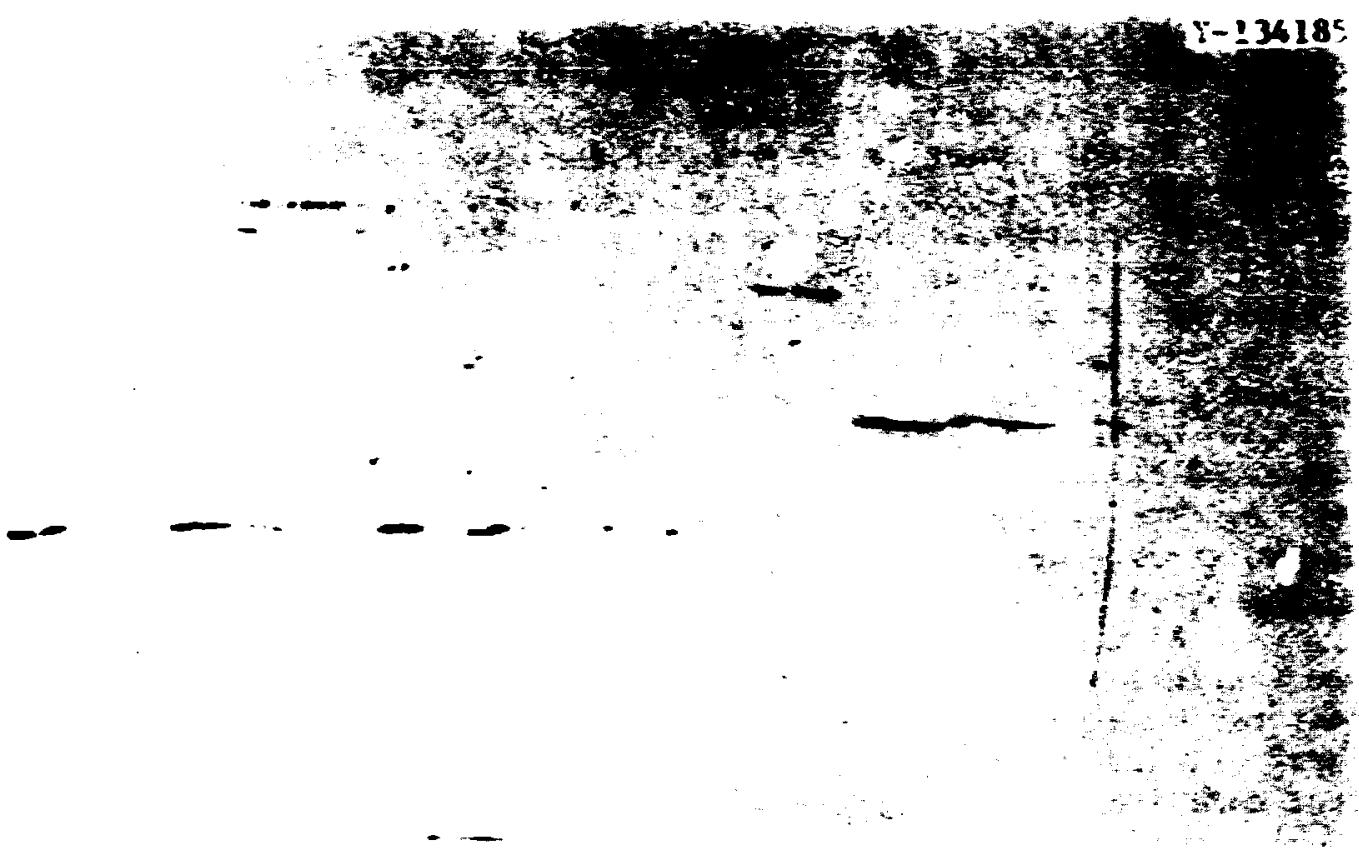

Fig. 8. Sulfide Stringers in the Interior of a Randonly Selected Section of Archive Tendons Employed in the Thereal Cylinder Test. $500 x$.

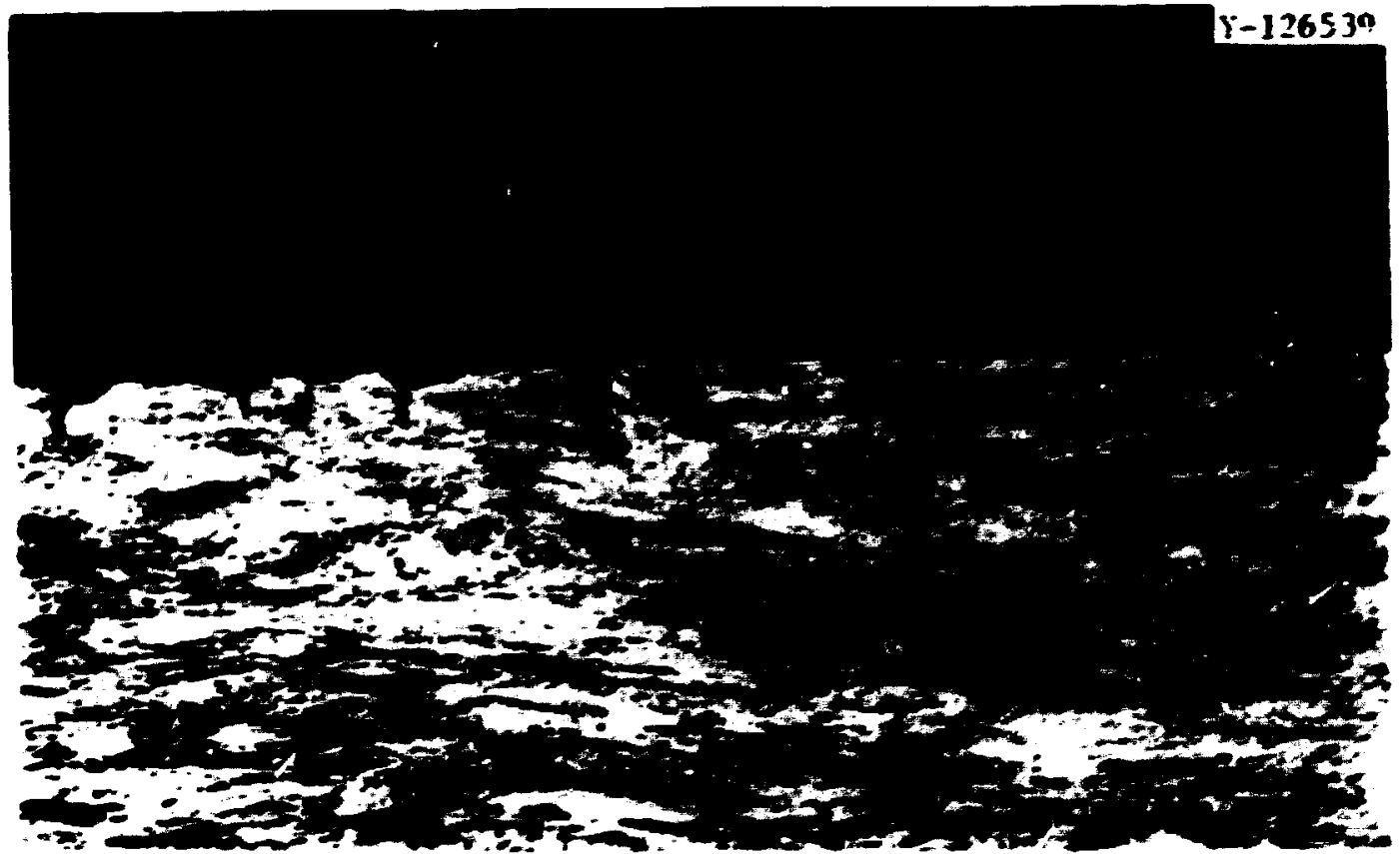

Fig. 9. Photonictograph of a Hire that Separated During a Centerless Grinding Operation. The cracks, wich are perpendicular to the longitudinal axis of the wire, could contribute to premature fallure. 
the present ly accepted tendon protection procedures exploying hermeticall: sealed ducts and protective coatings should prevent che type oi corrosion problens encountered in this particular experiment.

2. Stres-corrosion cracking of the vites used to manfacture the cendons eqployed in the thermal cylinder cest occurred in 72 hr or less in $0.2 \because$ solution of amalu aitrate at $70^{\circ} \mathrm{C}$.

3. Stress-corrosion cracking of the ufres did not occur in either a saturated or wery dilute (50 ppe) solution of matu nitrate at $70^{\circ} \mathrm{C}$.

4. Fallure did wot occur in u-bead specineas exposed to amoniu carbonate solutfoss of any concentration for over 94 days at $70^{\circ} \mathrm{C}$.

5. Addias 50 ppe mitrate to the amaiva carbonate solutions did not cause fallure during a 100 -day exposure at $66^{\circ}:$.

6. The cendoa fallures in the thermal cylinder test vere probably due to stress-corrosion cracting, possibly assited by the poor quality of the steel vires in the cendons.

7. An Inproper formation of the epoxy resia (excess hardener. see Conclustion 1) used to cont the botton plates of the thernal cylinder test ay have produced an eaviruneat that led to the crackints. This inproper formalation resulted in a hith level of aitrogen in the liquid chat cane into contact with the teadoas. Alchough cheadcal analysis shoued wost of the aftrogea to be amoniu nitrogen, lou leveis of aftrate aftrogen vere preseat.

8. Reversing the thermel gradient for 14 woths on two retensioned segreats from the thernal cylinder cest had no abservable effect on the load-carrying capacity of the teadons; cracking did we: occur.

9. The quality of the wires used to manfacture the ceadons exployed to the thermal cylinder test is questionale. Laps, cracks. and other evidence of exallurgically poor vire quality uere observed. (It should be enplasized that these if res represent che navifacturing prectices employed in the aid-1960s and ay not represeat current prectice.)

\section{Recomidutions}

1. The constructors of prest ressed conctete reactor vescels thould be alerted to the consequences of an improper fornulation of an epoxy resin sealent. Ordinarily. epoxy would not be eployed in MCKr construction, but there is evidence of its we in Engl and to repait volds or concrete hoaeycombing in the tendon anchorage regien of a vesel. In cases where siflar "protectiv" procedures are mployed, extrews care should be exercised to ensure that the tendon ducts are sealed and that excessive hardener is not employed in the epoxs aixture.

2. A critical assessment should be wade of the wire(s) that are ued in prestressing cendons. There is evidence that suggests that the wires used in the enufacture of the ASTM A 416 cendons employed in the Thermal Cylinder Experiment vere of questionsble quality. A study should be undertaken to determine whether or not the wites used in chis study represent current netallurgtes quality. 
3. In extensive parametric study should be conducted to deternine the threshould levels of contaniasents that are not detrimental to the load-carrying capacities of the teadons.

\section{ACROMLEDGETS}

The contributions fron the following personal to the informetion provided in this report are gratefully actuouledged: D. A. Costanzo and F. Layton for their assistance in the preparation of the spoxycarbonate solutions and for chenieal analysis of aterials from the test; C. C. Hurte for his assistance in tipe tup and operation of the retensioning experient; Paul haltom ar ay Xave for the metallographic and photographic work; Wada Dutcher, Judy Touas, Beredith Hill. and $c_{-g}$ Peterson for their assistance in the preparation of the muscript. 